\title{
HUMAN CAPITAL DAN PERANAN PEMERINTAH DALAM PENDIDIKAN
}

\section{SITI NURJANAH*}

\begin{abstract}
Human Capital is the knowledge, skills and abilities that can be used to produce a professional service. Human capital for the company is owned by its employees collective ability to create ideas, innovations and solutions appropriate to contribute to the achievement of corporate goals. For individuals, human capital is the ability to be able to win the competition in the world to provide more value in financial terms for workers. The government's role in education is to protect them and provide opportunities for educational equity, acted as a partner, companion, facilitator, public servants and funders; protect citizens from the negative influence of outside parties, giving equal opportunity to learn for every citizen. Government as mandate Act of 1945 shall establish and conduct a national education system for all citizens of Indonesia.
\end{abstract}

Keywords: Human capital, Role Of Goverment in Education

\section{PENDAHULUAN}

Pembicaraan tentang investasi sumber daya manusia (human capital investment) yang ternyata mampu memberikan konstribusi terhadap pertumbuhan ekonomi (economic growth), telah ada sejak jaman Adam Smith (1776), Heinrich Von Thunen (1875) dan para ilmuwan era ekonomi klasik lainnya sebelum abad ke-19

\footnotetext{
* Siti Nurjanah adalah dosen Fakultas Ekonomi Universitas Negeri Jakarta
}

yang menekankan pentingnya investasi untuk meningkatkan keterampilan sumberdaya manusia. Pada akhirnya, Schultz (1961) dan Deninson (1962) juga kemudian memperlihatkan bahwa pembangunan sektor pendidikan dengan sumberdaya manusia sebagai fokus intinya telah memberikan kontribusi langsung terhadap pertumbuhan ekonomi suatu negara, melalui peningkatan keterampilan dan kemampuan 
produksi dari tenaga kerja yang dimiliki perusahaan. Penemuan dan cara pandang ini telah mendorong ketertarikan sejumlah ahli untuk meneliti mengenai nilai ekonomi dari pendidikan (Nurulpaik, 2005). Kita akan sepaham bahwa semakin tinggi tingkat pendidikan seseorang maka semakin besar peluang untuk mendapat pekerjaan yang layak dan baik itulah jawaban umum di setiap era kehidupan bermasyarakat.

Dalam perkembangannya dahulu, pendidikan dalam pandangan tradisional selama sekian dekade dipahami sebagai bentuk pelayanan sosial yang harus diberikan kepada masyarakat, dalam konteks ini pelayanan pendidikan sebagai bagian dari public service atau jasa layanan umum dari sebuah negara kepada masyarakatnya, yang saat itu tidak nampak memberikan dampak langsung bagi perekonomian masyarakat sehingga pembangunan pendidikan tidak menarik untuk menjadi tema perhatian, kedudukannya tidak mendapat perhatian menarik dalam gerak langkah pembangunan. Namun, pada akhirnya disadari bahwa pendidikan memberikan pengaruh besar pada pertumbuhan ekonomi suatu bangsa.
Human capital merupakan sekumpulan dari kemampuan dan pengetahuan produktif manusia yang terdapat pada masyarakat. Memang, pada kenyataannya human capital merupakan investasi jangka panjang pada pengembangan sumberdaya manusia untuk meningkatkan produktivitas, kurang dapat terlihat dalam waktu yang singkat (instan). Pentingnya human capital adalah pengetahuan yang ada pada sumberdaya manusia merupakan basis penggerak dalam peningkatan produktivitas. Konsep human capital muncul karena adanya pergeseran peranan sumber daya manusia.

Human capital muncul dari pemikiran bahwa manusia merupakan intangible asset yang memiliki banyak kelebihan yaitu kemampuan manusia apabila digunakan dan disebarkan tidak akan berkurang melainkan bertambah baik bagi individu yang bersangkutan maupun bagi organisasi, manusia mampu mengubah data menjadi informasi yang bermakna, manusia mampu berbagi intelegensia dengan pihak lain 


\section{Human Capital}

Sumberdaya

manusia

merupakan asset terpenting dalam perusahaan, karena melalui keterampilan, keahlian dan pengetahuan yang dimiliki manusia dalam perusahaan atau organisasi tersebut akan mampu membawa perusahaan untuk memiliki kemampuan bertahan bahkan memenangkan setiap persaingan. Keunggulan kompetitif (competitive advantage) merupakan ciri khas perusahaan yang membedakan sebuah perusahaan dengan perusahaan lainnya, berupa kelebihan dan keunikan yang berbeda dibanding perusahaan lain atau bahkan para pesaing akan membawa sebuah organisasi/ perusahaan bertumbuh dan berkembang menghadapi segalam macam tantangan dan bahkan mampu memanfaatkan peluang yang ada.

Human Capital adalah kompetensi, pengetahuan, atribut sosial dan kepribadian, termasuk kreativitas,diwujudkan dalam kemampuan untuk melakukan pekerjaan sehingga menghasilkan nilai ekonomi (wikipedia) Faktor kunci dalam produksi adalah manusia, dan manusia adalah satusatunya faktor kesuksesan organisasi yang tidak diperdagangkan sebagai komoditas dagang organisasi (Holbeche, 2005). Selama ini, pengukuran kinerja organisasi hanya diukur melalui pencapaian finansial padahal pengukuran tersebut tidak merefleksikan daya saing yang sebenarnya dari organisasi dan belum mampu meramal kinerja organisasi di masa depan. Modal intelektual dan potensi inovasi merupakan kunci jangka panjang bagi "kesehatan" organisasi, dan bahwa manusia atau "human capital" merupakan sumber utama dari kedua aset tersebut.

Menurut Adam Smith (1776), Human Capital berupa kemampuan dan kecakapan yang diperoleh melalui pendidikan, belajar sendiri, belajar sambil bekerja dan untuk itu memerlukan biaya yang dikeluarkan oleh yang bersangkutan. Perolehan keterampilan dan kemampuan akan menghasilkan tingkat balik "Rate of Return"yang sangat tinggi terhadap penghasilan seseorang. Berdasarkan pendekatan Human Capital ada hubungan Linier antara Investasi Pendidikan dengan "Higher Productivity \& Higher Earning". Manusia sebagai modal dasar yang diinvestasikan akan menghasilkan 
manusia terdidik yang produktif dan meningkatkan penghasilan sebagai akibat dari kualitas kerja yang ditampilkan. Dalam perusahaan / organisasi human capital merupakan faktor sumberdaya manusia di dalam organisasi; berupa serangkaian gabungan kecerdasan, keterampilan dan keahlian yang memberikan ciri khas/ karakter organisasi.

Teori tentang human capital adalah suatu pemikiran yang menganggap bahwa manusia merupakan suatu bentuk kapital atau barang modal sebagaimana barang-barang modal lainnya, seperti tanah, gedung, mesin, dan sebagainya. Dalam skala makro (negara), human capital dapat didefinisikan sebagai jumlah total dari pengetahuan, skill, dan kecerdasan rakyat dari suatu negara.

$$
\text { Konsep Kapital Manusia }
$$

(Human Capital) diperkenalkan kembali oleh Theodore $\boldsymbol{W}$, Schultz lewat pidatonya yang berjudul "Investment In Human Capital" dihadapan pada ekonom Amerika pada tahun 1960, kemudian dipublikasikan melalui jurnal American Economic Review, pada Maret 1961. Sebelumnya, para ekonom hanya mengenal kapital fisik berupa alat-alat, mesin, dan peralatan produktif lainnya yang ditengarai memberikan konstribusi bagi pertumbuhan ekonomi dan pembangunan. Gagasan kapital manusia yang di ajukan oleh Schultz melalui "Investment In Human Capital" adalah bahwa proses perolehan pengetahuan dan keterampilan melalui pendidikan bukan sekedar sebagai suatu kegiatan konsumtif, melainkan suatu bentuk investasi Sumber Daya Manusia (SDM). Pendidikan, sebagai suatu sarana pengembangan kualitas manusia, memiliki konstribusi langsung terhadap pertumbuhan pendapatan negara melalui peningkatan keterampilan dan kemampuan produksi dari tenaga kerja.

Human capital merupakan salah satu konsep yang paling penting di dunia saat ini.Konsep ini sangat berpengaruh terutama, sekalipun mungkin tidak secara ekslusif, dalam bidang ekonomi. Dalam kerangka ini, human capital dianggap sangat berperan dalam pertumbuhan ekonomi dan kemakmuran sebuah negara. Oleh karenanya, negaranegara yang ingin menikmati pertumbuhan ekonomi dan kemakmuran harus memperhatikan 
dan mengembangkan secara serius human capital yang dimilikinya. Pengembangan human capital adalah sebuah bentuk investasi (investing in people) dan merupakan tuntutan dari ekonomi modern yang tidak bisa dihindarkan.

Seseorang atau karyawan yang memiliki kemampuan dan keterampilan dalam sebuah organisasi sangatlah berharga bagi perusahaan, dengan komitmen yang tinggi mereka akan mengerahkan segenap energi dan kemampuannya untuk memajukan organisasi dalam mencapai tujuannya. Bilamana para karyawan yang memiliki kompetensi tinggi ini meningkat maka produktivitas akan meningkat pula, melalui kegiatan organisasi yang efektif dan efisien, dengan demikian maka perusahaan memiliki nilai lebih dibandingkan pesaing mereka. Kemampuan perusahaan yang semakin meningkat akan memberikan dampak pada pertumbuhan organisasi dan pencapaian tujuan, setiap kegiatan organisasi dikelola dengan maksimal termasuk peningkatan pelayanan kepada para pelanggan.

Amstrong mengatakan

bahwa kesuksesan organisasi adalah produk dari kompetensi orang yang dimiliki organisasi, hubungan antara orang dan kinerja akan memberi manfaat untuk semua pemangku kepentingan. Karyawan yang memiliki kompetensi tinggi sangat dihargai perusahaan dan harus diberikan kepercayaan, diperlakukan dengan adil sehingga memberikan komitmen yang tinggi bagi perusahaan, pada gilirannya kinerja organisasi akan menjadi semakin meningkat pula.

\section{Peran Pemerintah dalam Pendidikan}

Pembukaan Undang-Undang Dasar Negara Republik Indonesia tahun 1945 (UUD 1945) mengamanatkan bahwa Pemerintah Negara Indonesia harus melindungi segenap bangsa Indonesia dan seluruh tumpah darah Indonesia dan untuk memajukan kesejahteraan umum, mencerdaskan kehidupan bangsa, dan ikut melaksanakan ketertiban dunia yang berdasarkan kemerdekaan, perdamaian abadi dan keadilan sosial. Dengan demikian, Pemerintah diwajibkan untuk mengusahakan dan menyelenggarakan satu sistem pendidikan nasional bagi seluruh warga negara Indonesia. Sistem pendidikan nasional dimaksud harus 
mampu menjamin pemerataan kesempatan dan peningkatan mutu pendidikan, terutama bagi anakanak, generasi penerus keberlangsungan dan kejayaan Bangsa dan Negara Kesatuan Republik Indonesia (NKRI).

Pendidikan merupakan salah satu faktor yang paling mendasar dalam siklus kehidupan manusia mulai lahir hingga akhir hayat (long life education). Secara konsep, pendidikan merupakan suatu upaya yang dilakukan secara sadar dan terencana untuk mencerdaskan kehidupan bangsa dan mengembangkan manusia Indonesia seutuhnya agar menjadi manusia yang beriman dan bertakwa kepada Tuhan Yang Maha Esa, berakhlak mulia, sehat, berilmu, cakap, kreatif, mandiri, dan menjadi warga negara yang demokratis serta bertanggung jawab. Pendidikan adalah suatu proses transfer of knowledge (ilmu pengetahuan, teknologi dan seni) yang dilakukan oleh guru kepada anak didiknya. Selain itu, pendidikan adalah alat untuk merubah cara berpikir kita dari cara berpikir tradisional ke cara berpikir ilmiah (modern).

\begin{tabular}{lrr}
\multicolumn{2}{c}{ Pemerintah } & memegang \\
peranan & penting & dalam \\
meningkatkan & kualitas & pendidikan
\end{tabular}

anak-anak Indonesia, utamanya mulai dari ketersediaan sarana dan prasarana minimal berupa gedung sekolah yang layak, hingga sampai pada ketersediaan berbagai fasilitas pendukung pendidikan lainnya. Selain ketersediaan sarana dan prasarana fisik dan berbagai fasilitas pendukung pendidikan lainnya yang masih terbatas dan belum menjangkau seluruh wilayah NKRI, kurikulum pendidikan dasar pun menjadi permasalahan. Kurikulum yang seringkali berubah seiring dengan pergantian rezim pemerintahan menyebabkan anakanak usia sekolah dasar menjadi korbannya. Pemerintah harus menyadari bahwasannya anak-anak merupakan investasi masa depan sebuah bangsa. Merekalah yang kelak akan mengisi ruang-ruang proses berbangsa dan bernegara. Wajar saja ketika banyak orang menyerukan bahwa anak adalah bibit-bibit atau tunas yang harus diperhatikan dan dirawat dengan baik. Merekalah pewaris masa depan, tulang punggung dan harapan bangsa dan negara ada di pundak mereka. Namun, harapan itu ternyata masih membentur tembok yang sangat besar. Ternyata masih banyak di temukan anak-anak kurang mampu harus 
berhenti sekolah karena tidak memiliki biaya.

Beberapa peran yang diharapkan dapat dimainkan oleh aparat pemerintah dalam menata dan memantapkan pelaksanaan pendidikan menurut Sihombing (2001) adalah: (1) peran sebagai pelayan masyarakat, (2) peran sebagai fasilitator, (3) peran sebagai pendamping, (4) peran sebagai mitra dan (5) peran sebagai penyandang dana. Sebagai Pelayan Masyarakat, pemerintah harus memberikan pelayanan terbaik bagi masyarakat. Melayani masyarakat, merupakan pilar utama dalam memberdayakan dan membantu masyarakat dalam menemukan kekuatan dirinya untuk bisa berkembang secara optimal. Masyarakat harus diposisikan sebagai fokus pelayanan utama. Sebagai Fasilitator, pemerintah seharusnya merupakan fasilitator yang ramah, menyatu dengan masyarakat, bersahabat, menghargai masyarakat, mampu menangkap aspirasi masyarakat, mampu membuka jalan, mampu membantu menemukan peluang, mampu memberikan dukungan, mampu meringankan beban pekerjaan masyarakat, mampu menghidupkan komunikasi dan partisipasi masyarakat tanpa masyarakat merasa terbebani.

\section{Sebagai}

Pendamping, pemerintah harus melepaskan perannya dari penentu segalanya dalam pengembangan program belajar menjadi pendamping masyarakat yang setiap saat harus melayani dan memfasilitasi berbagai kebutuhan dan aktivitas masyarakat. Sebagai Mitra, apabila kita berangkat dari konsep pemberdayaan yang menempatkan masyarakat sebagai subjek, maka masyarakat harus dianggap sebagai mitra. Hubungan dalam pengambilan keputusan bersifat horizontal, sejajar, setara dalam satu jalur yang sama. Sebagai mitra, pemerintah harus dapat saling memberi, saling mengisi, saling mendukung dan tidak berseberangan dengan masyarakat, tidak terlalu banyak campur tangan yang akan menyusahkan, membuat masyarakat pasif dan akhirnya mematikan kreativitas masyarakat. Sebagai Penyandang Dana, pemerintah harus memahami bahwa masyarakat yang dilayani pada umumnya adalah masyarakat yang kurang mampu, baik dalam ilmu maupun ekonomi. Untuk itu diperlukan modal sebagai modal dasar untuk menerapkan apa yang 
diyakininya dapat dijadikan sebagai sumber kehidupan dari apa yang sudah dipelajarinya. Pemerintah berperan sebagai penyedia dana yang dapat mendukung keseluruhan kegiatan pendidikan yang diperlukan oleh masyarakat.

\section{DAFTAR PUSTAKA}

Becker, G.S, 1964. Human Capital $A$ Theoritical and Empirical Analysis, with Special Reference to Education, University of Chicago Press.

Brewer, Dominic J \& Mc Ewan, Patrick J. 2010. Economics of Educations, Elsevier
Jordan Hill Oxford, San Diego, USA.

Coleman, J.S. Campbell,E.Q. Hobson C] et.all. 1966. Equality of Educational Opportunity , Governmet Printing Office, Washington DC, USA.

INVESTASI DALAM SUMBER DAYA MANUSIA - Ekonomi Pendidikan http://pustaka.ut.ac.id/pusla ta/online

Nurul Kusuma Putri, Pengaruh Human Capital pada Kesusksesan Organisasi

http://arjunabelajar.blogspot.com/2 $\underline{011 / 03 / v-}$ behaviorurldefaultvmlo 